\title{
Krydsmodel for under- visningstilrettelæggelse
}

\author{
Af Jeppe Bundsgaard, lektor, ph.d., Danmarks Pedagogiske Universitetsskole, Aarhus Universitet
}

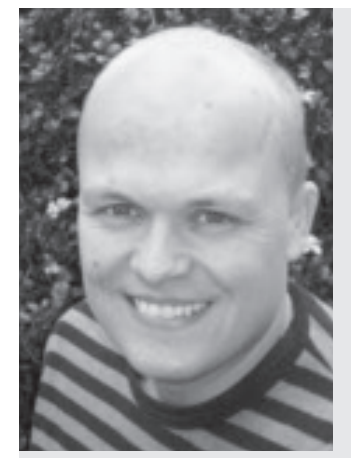

Jeppe Bundsgaard er lektor i kommunikative kompetencer ved Danmarks Pædagogiske Universitetsskole, Aarhus Universitet. Han underviser på uddannelserne i didaktik med sær ligt henblik på dansk og it-didaktisk design og forsker i itdidaktik og kompetenceorienterede logikker for curriculumudvælgelse.

\section{Reviewet artikel}

I denne artikel presenteres en krydsmodel over undervisningsformers organiseringstyper med modsatningen monologisk-dialogisk på den ene akse og lererstyret-studenterstyret på den anden akse. Inden for hver kvadrant beskrives en typisk undervisningsform, og gennem en analyse af fordele og ulemper ved de forskellige undervisningsformer argumenteres for, at det er en fordel at variere undervisningsformerne ved tilrettelaggelse af universitetsundervisning, således at der finder undervisning sted inden for alle fire kvadranter. Denne argumentation underbygges af en empirisk undersogelse af de studerendes opfattelse af lacingsudbytte på et modul, der er tilrettelagt med undervisning inden for alle fire kvadranter $i$ krydsmodellen.

\section{Indledning}

De fleste moduler (også kaldet kursusforløb) på de danske (humanistiske) universitetsuddannelser er tilrettelagt som en række forelæsninger eller lærerstyrede undervisningssessioner med læreren som den mest talende og de studerende som tilhørere, spørgsmålsstillere og opgaveskrivere. Der kan være mange gode grunde til denne praksis, men der er også mange grunde til, at det ikke er den mest hensigtsmæssige måde at tilrettelægge et læringsforløb på.

På Danmarks Pædagogiske Universitetsskole ved Aarhus Universitet har vi mange moduler, der følger den traditionelle opskrift, men gør også forsøg med andre organiseringer. Et af disse forsøg er modulet Curriculumteori og institutionsdidaktik på didaktik-uddannelsen. Dette modul er tilrettelagt som en kombination af flere undervisningsmetoder heriblandt forelæsninger, diskussioner på mindre hold, løbende skriftlig produktion og studenterstyrede diskussioner. Modulet udbydes både som et fremmødehold i København og som et fjernundervisningshold i Århus. De fjernstuderende følger forelæsningsrækken på video, der lægges på internettet et par dage efter forelæsningen.

I denne artikel præsenteres en krydsmodel til analyse af undervisningstilrettelæggelse. Det er hypotesen, at modellen kan anvendes ved vurdering af om et givet modul stiller tilstrækkeligt varierede læringsmuligheder til rådighed for de studerende.

Krydsmodellen anvendes som grundlag for en analyse af modulet Curriculumteori og institutionsdidaktik med henblik på diskussion af modellens anvendelighed og med henblik på diskussion af, om man kan argumentere for, at et modul med varierede undervisningsformer fremmer de studerendes læring mere end traditionelt tilrettelagte moduler.

Diskussionen i nærværende artikel er overvejende teoretisk. En empirisk argumentation for modellen antydes gennem behandling af en spørgeskemaundersøgelse blandt alle studerende, der har deltaget i Curriculumteori og institutionsdidaktik gennem de 3 semestre, det har været udbudt. Men der vil være behov for yderligere empiriske undersøgelser.

\section{Hvad lærer man mest af?}

Den såkaldte Læringspyramide gengives og anvendes i en lang række bøger, læringsresurser og peer reviewede artikler (Lalley \& Miller, 2007, s. 64). Den er udviklet af National Training Laboratories, Bethel Maine og beskriver forskellen i, hvad der fastholdes (retention rate), alt efter hvilken undervisningsmetode man anvender. Modellen ser således ud:

Det fremgår fx at man fastholder omkring $20 \%$ af, hvad man hører til en forelæsning. Eller faktisk afhænger det af, hvilken udgave af læringspyramiden man tager udgangspunkt i. Andre versioner angiver $\mathrm{fx}$, at man fastholder $5 \%$ af en forelæsning (Lalley \& Miller, 2007, s. 69). Lalley og Miller har undersøgt læringspyramidens genese, og det viser sig, at den 


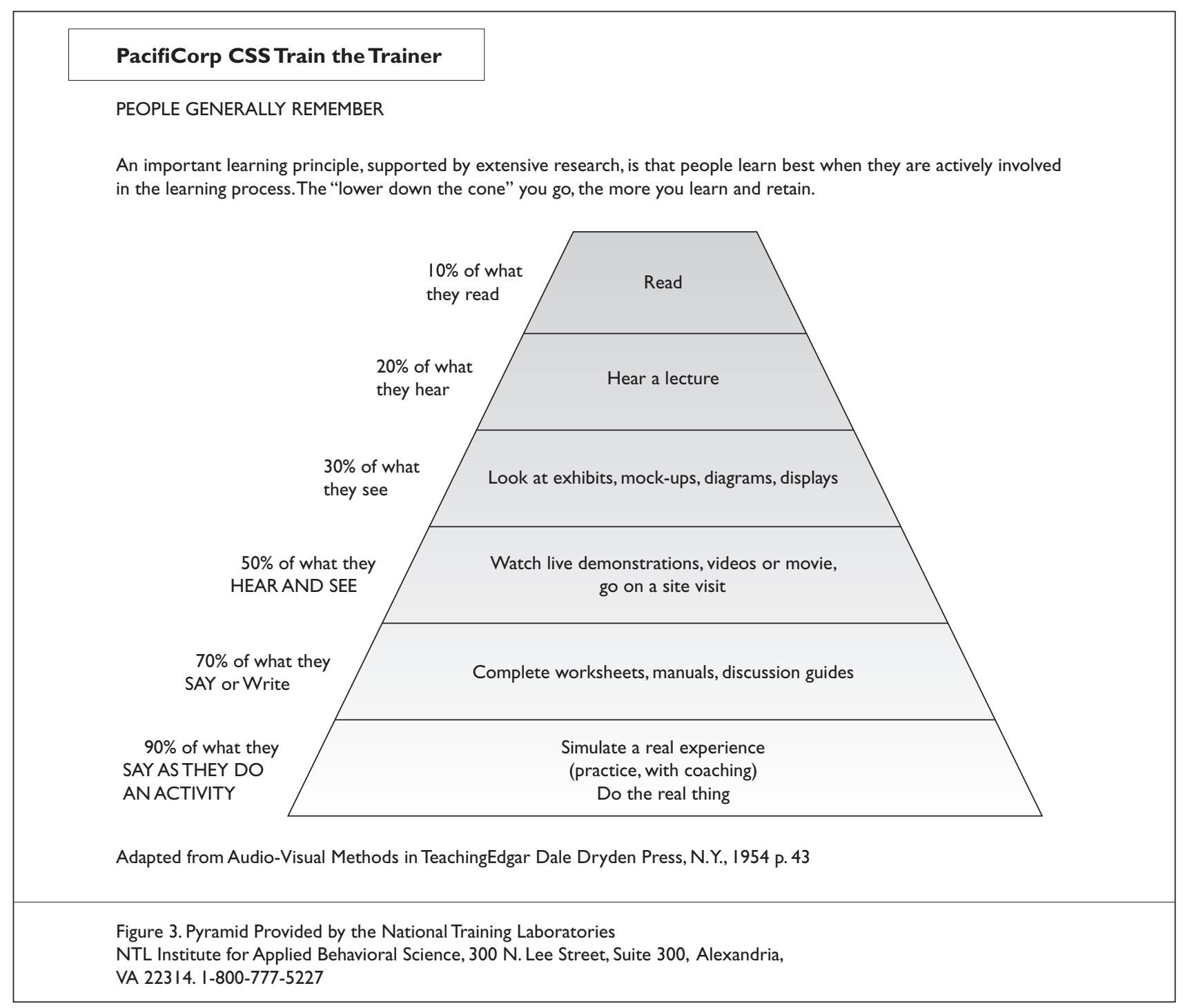

Figur I. The learning Pyramid, National Training Laboratories, Bethel Maine. Her gengivet efter Lalley \& Miller (2007, s. 68).

fortaber sig i tågerne. Efter al sandsynlighed er den udviklet ud fra en Cone of Experience, som den amerikanske uddannelsesforsker Edgar Dale præsenterede i flere udgaver i midten af 1940'erne og 1950'erne (fx Dale, 1946). Denne Cone of Experience er bygget på spekulative overvejelser over, hvor tæt på konkrete erfaringer og derfor hvor memorable undervisning med forskellige modaliteter er. Læringspyramiden, som stadig af ophavsinstitutionen præsenteres som baseret på "extensive research" (se modellens øverste caption), er således i virkeligheden uden forskningsmæssigt belæg! Og det ville være yderst vanskeligt at skaffe det til veje (Lalley \& Miller, 2007, s. 70).

Lalley og Miller sætter sig for, at undersøge, hvad der faktisk er belæg for at sige om hvilke metoder der fungerer bedst. De gengiver resultater fra en række metastudier og individuelle studier i forhold til de spørgsmål, hvor der ikke har været metastudier at tage udgangspunkt i. De konkluderer at:

The research reviewed here demonstrates that use of each of the methods identified by the pyramid resulted in retention, with none being consistently superior to the others and all being effective in certain contexts (Lalley \& Miller, 2007, s. 76).

Lalley og Miller anbefaler således at metoderne tænkes som et kontinuum i stedet for som et hierarki (Lalley \& Miller, 2007, s. 76). Og dette făr dem til at vende tilbage til de pointer som allerede (Dewey, 2005 (1916)) formulerede, nemlig:

[...] for successful learning experiences, students need to experience a variety of instructional methods and that direct instruction needs to be accompanied by methods that further student understanding and recognize why what they are learning is useful (Lalley \& Miller, 2007, s. 76).

God undervisning hviler således, ifølge (Lalley \& Miller, 2007, s. 70), på en balanceret kombination af de forskellige metoder, afhængig af indhold, lærerens baggrundsviden, resurser og de studerendes særpræg. 


\section{Krydsmodellen for undervisningsformers organiseringstyper}

Lalley og Miller anbefaler at betragte undervisningsmetoderne som liggende på et kontinuum, hvor alle metoderne har fordele og ulemper. Denne forskningsbaserede indsigt er et afgørende vigtigt opgør med læringspyramiden, men kontinuum-figuren bestemmes ikke nærmere, og den giver ikke en logik eller principper for tilrettelæggelse af undervisning. Det er denne artikels mål at præsentere en sådan logik i form af en konceptualiseringsmodel til brug ved analyse af undervisningstilrettelæggelse i form af en firefeltsmodel (kaldet Krydsmodellen) med modsæetningen monologiskdialogisk på den ene akse og lærerstyret-studenterstyret på den anden akse.

Man kan altså tegne følgende model over emne-/ indholdsorienterede undervisningsformers organisering:

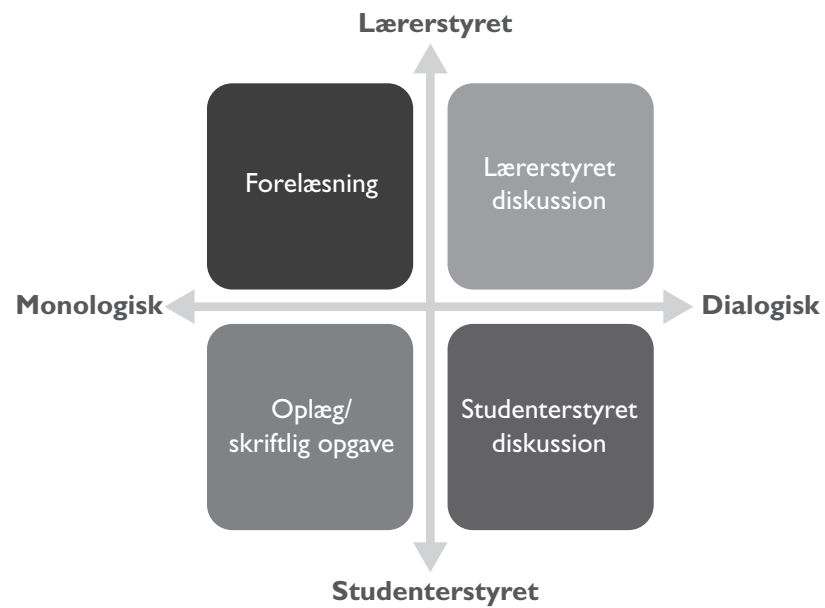

Figur 2. Bundsgaards krydsmodel over emne-/indholdsorienterede undervisningsformers organiseringstyper

Aksen fra monologisk til dialogisk angiver, at undervisning kan være mere eller mindre båret af én stemme eller af en række enetaler, og mere eller mindre udtryk for samtale og gensidig forholden sig. Den dialogiske såvel som den monologiske form kan finde sted både i den store forsamling og i mindre grupper.

Aksen fra studenterstyret til lærerstyret angiver, hvor stor indflydelse den studerende har på, hvad der foregår. En rent lærerstyret undervisning vil være helt ufølsom over for studenterforudsætninger, således at der ved undervisning forstås formidling af et forud defineret indhold uanset om de studerende forstår, hvad der undervises i. Den fuldt studenterstyrede undervisning kan ikke betegnes som undervisning, men som selvstudier eller forskningsfællesskaber.

Som det fremgår, er der en række protypiske undervisningsformer, der placerer sig forskellige steder i krydsmodellen. Forelæsningen som den typiske lærerstyrede monologiske form, den lærerstyrede diskussion som den typiske lærerstyrede dialogiske form, det mundtlige oplæg eller den skriftlige opgave som den typiske studenterstyrede monologiske form og den studenterstyrede diskussion som den typiske studenterstyrede dialogiske form. Der findes naturligvis mange genrer inden for hvert af de fire felter. Lærebogen kan fx betragtes som en lærerstyret monologisk form, mens forståelsesspørgsmål i lærebogen bevæger den mod en mere dialogisk form. Projektarbejde i grupper er et andet eksempel på en studenterstyret dialogisk form.

Modellen kan ikke rumme forskellen på mere situerede, $\mathrm{fx}$ projektorganiserede, og mere laboratorieprægede, fx opgaveløsningsmæssige, former. Det ville kræve en tredje akse, som man kunne kalde opgave- eller projektaksen. I Curriculumteori og institutionsdidaktik findes aktiviteter fra det næsten formelt opgaveløsende (referat af en teori) til det forholdsvis projektorienterede $\mathrm{i}$ form af eksamensopgaven. Denne akse er ikke i fokus i denne sammenhæng.

En fjerde akse, man kunne overveje at arbejde med $i$ en figur, der da måtte formes anderledes (da fire dimensioner er vanskelige at gengive $i$ to dimensioner), ville være indholdsaksen fra det stoforienterede til det kompetenceorienterede.

Men disse ekstra akser er ikke medtaget i denne model, da den alene er beregnet til vurdering af tilrettelæggelse af undervisningsformer, og den kan således ikke stå alene, men må suppleres af vurdering af studenterforudsætninger, underviseres indstilling, opgavetyper, pensummængde og -udvalg (jf. Bundsgaard, 2006), undervisningens relation til eksamensformen (jf. Biggs, 1999) m.m.

\section{Undervisningsformer}

I det følgende tages de prototypiske undervisningsformer op til nærmere undersøgelse med henblik på at argumentere for, at et velfungerende undervisningsforløb så vidt muligt inddrager undervisningsformer inden for alle fire felter i krydsmodellen. Målet er således at diskutere fordele og ulemper ved hver enkelt prototypiske undervisningsform for derigennem at begrunde nødvendigheden af variation af undervisningsformerne.

\section{Foreloesninger}

Forelæsninger defineres her som en undervisningssituation, hvor en forelæser holder en forberedt enetale om et fagligt emne for en større eller mindre gruppe af tilhørere. Der kan stilles opklarende spørgsmål fra tilhørerne, men det vil sjældent give anledning til egentlige meningsudvekslinger. Læreren er autoriteten og bestemmer, om andre deltagere kan komme til orde.

Når undervisning foregår på store hold, kan det være svært at skabe en dialog mellem mere end en brøkdel af deltagerne - og svært at have en dialog som opleves som relevant af alle. Derfor kan det opleves som den eneste løsning at forelæse. Forelæsningen (den veludførte af slagsen) sikrer, at der faktisk 
er fagligt indhold, og gør det muligt at sikre, at de studerende bliver præsenteret for de centrale pointer og væsentligste områder: »lecturing has been found to be an effective method when gaining knowledge of facts is the intended outcome« (Saroyan \& Snell, 1997). Forelæsningen imødekommer samtidig en forventning om, at underviseren skal bidrage med sin store faglige viden - "når ikke vi har mere tid, så skal vi have meget ud af den".

På den anden side viser empiriske undersøgelser (med al den usikkerhed de giver), at tilhørere til forelæsninger ikke kan koncentrere sig meget mere end 15 minutter (Van der Vleuten, 1996, s. 4). Forelæsninger făr oftest karakter af præsentationer af informationer og teorier, af "facts". Men kompetence er mere end viden om facts. Kompetence består i evne til at kunne se centrale muligheder og udfordringer $i$ en situation og $\mathrm{i}$ at kunne handle $\mathrm{i}$ forhold til denne forståelse (Rychen \& Salganik, 2003; Jørgensen, 1999). Det vil sige, at for at være kompetent skal man have viden og forståelse, kognitive og praktiske evner, holdning til situationens udfordringer, og motivation for at møde disse (jf. Bundsgaard, 2006). Kompetencer er således meget svære at udvikle alene igennem forelæsninger.

Et yderligere problem ved forelæsninger er problemet om studenterforudsætning. Graden af feedback ved forelæsninger er lav - forelæseren kan sjældent afgøre, om det, han eller hun siger, er for let, for svært, for velkendt eller uvedkommende for de studerende. Og det er yderst vanskeligt at differentiere i forhold til forskellige grupper af studerendes forudsætninger.

\section{Larerstyrede diskussioner}

Lærerstyrede diskussioner defineres som diskussioner, hvor læreren er ordstyrer, har et fagligt mål med diskussionerne og har til hensigt at få de studerende til at deltage $i$ den igangsatte diskussion. Læreren er autoriteten og kan til hver en tid tage ordet. Det, læreren siger, betragtes oftest som et privilegeret og mere rigtigt udsagn end det, de studerende siger.

Ved selv at formulere sig om emnet/problemstillingen/det faglige stof gør de studerende emnet/problemstillingen til deres egen - de relaterer problemstillingen til de erfaringer, de har (Dewey, 2005, s. 162ff.). Ordet fagligt stof skal i denne sammenhæng forstås bredt som indhold $\mathrm{i}$ form af teorier om genstandsfeltet, indsigt $\mathrm{i}$ forskellige teorier og indhold af mere metodisk, aktivitetspræget form, dvs. analysetilgange (metoder), faglige diskursformer osv. Dvs. alle de ting der gør en fagperson til fagperson.

Dialog, analyse, syntese, fortolkning, diskussion osv. er netop nogle af de aktivitetsformer, den kompetente akademiker skal kunne udføre i sin praksis - og derved formidler undervisningen ikke blot viden, men understøtter mere bredt kompetencer. Underviseren kan desuden gennem dialogen fă et indblik i, hvad der er svært og hvad der er let, hvor de studerende trænger til at få deres fordomme udfordret, hvad der særlig interesserer de studerende osv.

Ved at sætte spørgsmål til debat skabes der rum for, at deltagerne aktivt tager stilling, hvorved de studerende făr konkret erfaring med de forskellige vinkler, emnet kan anskues fra - og aktivitet modvirker koncentrationssvigt. Gennem dialogen kommer flere deltagere til orde og får derved lejlighed til at skabe sig en relation til emnet.

Men dialogprægede aktiviteter kan give deltagerne en oplevelse af, at der ikke bringes tilstrækkeligt med fagligt stof i spil, og dialogprægede aktiviteter kan føre til ukvalificerede og decideret forkerte udsagn eller til en oplevelse af, at undervisningen ikke bevæger sig fremad, men ender i snak. Når læreren styrer diskussionen, kan hans eller hendes dagsorden opleves som irrelevant af de studerende - diskussionsemnerne kan være af for abstrakt, teoretisk karakter, eller de kan opleves som for lette, selvindlysende, omhandle emner som de studerende ikke interesserer sig for osv.

\section{Studenterstyret diskussion}

Studenterstyret diskussion er en diskussion uden deltagelse af lærer, eller hvor læreren deltager på lige fod med de studerende, evt. underlagt en ordstyrers autoritet. Det kan være i studiegrupper eller i gruppearbejde eller i plenum ofte på baggrund af studenteroplæg. Det kan også være ved svar på spørgsmål, læreren har sat til debat. Her er der dog tale om en mellemform, fordi lærerens dagsorden bliver styrende.

Den studenterstyrede diskussion kan naturligvis foregå i undervisning med læreren som deltager, men ofte vil både studerende og lærer anse det for uhensigtsmæssig brug af lærerens tid. Derfor foregår studenterstyrede diskussioner ofte enten i mere uformelle sammenhænge, når studerende skriver opgaver sammen eller mødes i studiegrupper. Eller slet ikke. Der er flere grunde til, at den studenterstyrede diskussion kan være hensigtsmæssig for de studerendes læring.

Studenterstyret diskussion har samme fordele og ulemper som lærerstyrede diskussioner. Dertil kommer, at de studerende bestemmer vinklen og derigennem relevansen for deres eget (ud-)dannelsesprojekt, at autoritetsforholdet i diskussionen nivelleres, således at der ikke er en særligt privilegeret stemme, et standpunkt som er særlig svært at kritisere; desuden kan holdninger og forståelser, man er usikker på, prøves af. Studenterstyrede diskussioner kan betragtes som samarbejdende læring, og i en metaanalyse, der inkluderer 164 studier af udbytte af cooperative learning, konkluderer Johnson, Johnson \& Stanne at »cooperative learning methods had a significant positive impact on student achievement" (Johnson, Johnson \& Stanne, 2000) sammenlignet med konkurrence- eller individuelle arbejdsmetoder.

Men i studenterstyrede diskussioner kan misforståelser reproduceres, opfattelser kan holdes på det overfla- 
diske plan uden den dybde, som kendetegner egentligt akademiske dialoger, og fordomsfulde og ubegrundede holdninger kan understøttes og udbredes.

\section{Studentermonologer}

Studentermonologer kan være både skriftlige og mundtlige, fx i form af et forberedt oplæe, eller skriftlige oplæg undervejs i undervisningsforløbet eller til eksamen.

Ved studentermonologer făr den studerende lejlighed til at beskæftige sig med stoffet med henblik på at skabe overblik, komme til forståelse af området osv. Når man arbejder med et stof og skal præsentere sin forståelse for medstuderende og/eller undervisere, opdager man, hvor man har lakuner, hvad man ikke kan forklare, hvad man mangler at beskæftige sig med osv. Hvis studentermonologer er obligatoriske eller giver afløsning for dele af eksamenskravet, tvinges de studerende til faktisk at deltage i forelæsninger og/ eller læse litteraturen i stedet for at udskyde studierne til sidste øjeblik. Løbende skriftlighed giver den studerende mulighed for at komme dybere ned i stoffet end ved blot at lytte og læse.

Men studenteroplæg, der er dårligt forberedte eller formidler forkerte forståelser, kan være svære at gardere sig imod som lærer, og det kan være svært at gribe ind på rette tid. Og det kræver et meget stort ekstraarbejde at forholde sig til skriftlige oplæg fra mange studerende, hvis ikke det er en del af eksamen eller på anden måde godskrives i lærerens arbejdstid.

\section{Curriculumteori og institutionsdidaktik}

I det følgende diskuteres modulet Curriculumteori og institutionsdidaktik ud fra krydsmodellens analysetilgang og der argumenteres for, hvorfor organiseringen er hensigtsmæssig.

Curriculumteori og institutionsdidaktik er (i udgangspunktet af økonomiske årsager) et samlæst modul for alle didaktikuddannelsens retninger på Danmarks Pædagogiske Universitetsskole. Der er således omkring 80 studerende på modulet i København. Derfor er det tilrettelagt som en række forelæsninger forestået af forskellige undervisere. Der er desuden inden for timetalsmodellen plads til, at der også kan afholdes en række fagdelte seminarer. Jeg er overordnet modulansvarlig og underviser på det fagdelte hold for danskstuderende.

Forelæsninger er, som antydet tidligere, en form der egner sig til fremlæggelse af deklarativ viden og til at fremlægge bud på sammenhænge mellem perspektiver, teorier, tilgange, forståelser inden for det faglige felt (under ét kaldet stoffet). Men formen er ikke velegnet til at understøtte de studerendes integration af stoffet $i$ deres egen kognitive struktur, endsige i deres affektive, kropslige og motivationelle strukturer. De studerende skal med andre ord arbejde med stoffet uden for forelæsningsrummet for at nå til en dybere integration. Det understøttes altid gennem de givne eksamensformer, som på DPU ofte er projektopgaver med vejledning og eventuelt en mundtlig eksamination. Denne form, der befinder sig inden for krydsmodellens nederste venstre felt, studenterstyret monologisk, fremmer de studerendes fordybelse $i$ et fagligt område med sig selv og i nogen grad vejlederen som samtalepartner. Fordybelsen i et område kan begrundes ud fra et eksemplarisk princip: Gennem at arbejde i dybden og problemorienteret med et snævert område af det faglige felt udvikler den studerende kompetencer, som hun kan anvende i forhold til de andre områder af fagområdet. Men med så store og heterogene områder som modulet Curriculumteori og institutionsdidaktik omfatter, så er virkeliggørelsen af dette eksemplariske princip mere en utopi end en realitet. Dette er en af grundene til at der er indlagt de såkaldte overblikspapirer i modulet. Overblikspapirerne fungerer som de studerendes individuelle behandling af det ret heterogene og omfattende område, som modulet dækker. Overblikspapirerne afleveres nogle dage for de fagdelte undervisningsgange (se nedenfor) og skal kommenteres gensidigt af de studerende. De danner derefter udgangspunkt for diskussionerne på de fagdelte undervisningsgange.

Der er flere argumenter for at studerende løbende skriver overblikspapirer, hvoraf de vigtigste er, at de studerende arbejder med stoffet ud fra deres egen vinkel, fordeler arbejdsbyrden mere jævnt over semesteret og træner akademiske arbejdsformer, samt at underviseren får løbende indblik i de studerendes akademiske og faglige kompetencer.

Der er således tale om, at der sker en løbende formativ evaluering af såvel de studerendes udvikling som af modulets form og indhold. Denne formative evaluering, der siger noget om den indholdsmæssige målopfyldelse af undervisningen, suppleres desuden af en evaluering af de studerendes tilfredshed og af deres oplevelse af undervisningens planlægning og tilrettelæggelse, deres egen indsats, samt den indholdsmæssige relevans.

\section{Larerstyrede diskussioner på seminarer}

Øvrigt arbejde med stoffet i form af diskussioner, kritik, skabelse af overblik over hele modulets indhold og indre logikker, kan naturligvis overlades til de studerende selv - og bliver det ofte. Men i Curriculumteori og institutionsdidaktik er dette arbejde understøttet gennem tilrettelæggelsen af modulets undervisningsformer. Der er således 45 fagdelte undervisningsgange, hvor de studerende mødes i mindre grupper med en underviser inden for de studerendes studiegren. På danskgrenen er disse fagdelte undervisningsgange tilrettelagt ud fra en vurdering af, at de studerendes læreproces fremmes af at indgå $\mathrm{i}$ en diskussion af det faglige stof ved at kritisere og finde anvendelser af teorier og metoder, foretage analyser af konkrete eksempler på empiri, overveje sammenhænge og diskutere de forskellige perspektiver. 
Derved får de studerende afprøvet nogle af de arbejdsformer som forskere udfolder, og de făr lejlighed til at gøre det faglige stof relevant $\mathrm{i}$ deres egen nuværende praksis og $i$ en fremtidig praksis fx som seminarielærere eller udviklingskonsulenter.

Diskussionerne tager ofte udgangspunkt i de studerendes overblikspapirer, som derfor kan ses som studenterinitierede oplæg til en lærerstyret dialog, og den fagdelte undervisning kan således siges at befinde sig på overgangen mellem øvre og nedre højre felt i krydsmodellen.

Diskussionerne giver desuden underviseren indblik i, hvad de studerende lærer, og bidrager således også til den formative evaluering af modulets tilrettelæggelse.

Som det fremgår, lægger denne organisering af modulet op til organiserede aktiviteter inden for tre (og en halv) af de fire kvadranter i krydsmodellen over undervisningens organiseringsformer: Forelæsninger, studenteroplæg og lærerstyret diskussion.

\section{Weblogs og studenterstyrede diskussioner}

Didaktik med særligt henblik på dansk-uddannelsen udbydes også i Århus. I Århus-udgaven af modulet indebærer organiseringen også aktiviteter inden for den sidste kvadrant. Alle forelæsninger i København videooptages og streames så de er tilgængelige for de studerende i Århus (og København) et par dage efter, at de har fundet sted. Der er indlagt 4 seminargange $i$ Århus med deltagelse af en underviser. Og endelig er overblikspapirerne erstattet af weblogs. De studerende skal efter hver forelæsning skrive en weblog. Weblogs er en webbaseret teknologi til skrivning af mere personligt vinklede overvejelser over alt fra politik til privatliv. I denne sammenhæng er kravet, at de studerende i deres weblogs skal behandle forelæsningens indhold enten gennem referat, relatering til personlige erfaringer, diskussion eller lignende.

Et af de væsentlige træk ved weblogs er, at læserne har adgang til at svare og diskutere indholdet $\mathrm{i}$ blogindlæggene. Dette træk er ligeledes gjort til en del af de studerendes forpligtelse, således at de skal svare på mindst et tilsvarende antal weblogs som de skal skrive. Derved indgår de studerende i en studenterstyret diskussion, som kan følges af læreren.

I denne organisering er de studerende meget aktive både gennem at danne sig overblik over, tilrettelægge og tage stilling til stoffet, gennem at diskutere hinandens vinkler på stoffet og gennem at deltage $i$ de lærerstyrede diskussioner. Og de studerende făr adgang til stoffet gennem såvel skriftlige tekster, forelæsninger samt lærerens diskuterende oplæg til diskussion.

Weblogorganiseringen repræsenterer således aktiviteter i alle fire kvadranter: videooptagne forelæsninger, studenteroplæg i form af weblogs, studenterstyret diskussion på baggrund af weblogs og lærerstyrede diskussioner på baggrund af forelæsninger og weblogs med tilhørende diskussioner.

\section{Empirisk befæstelse}

Krydsmodellen er teoretisk konciperet. Med den hævder jeg implicit, at den mest lærerige undervisning er tilrettelagt, så der er aktiviteter inden for alle fire kvadranter. Dette udsagn kan befæstes empirisk gennem undersøgelser af moduler der er forskelligt tilrettelagt (med forskellige kombinationer af aktiviteter inden for en eller flere kvadranter). Jeg har foretaget, hvad der kan betragtes som en pilotundersøgelse for en større empirisk undersøgelse. Spørgsmålet, jeg her behandler, er et blandt flere $\mathrm{i}$ en undersøgelse blandt de studerende på Curriculumteori og institutionsdidaktik om deres vurdering af eget læringsudbytte. Undersøgelsen bygger på et webspørgeskema, som alle studerende, der har deltaget på modulet et af de tre semestre, det har været udbudt, er blevet bedt om at svare på. 157 studerende er blevet spurgt. Blandt dem er sandsynligvis nogle, som ikke længere studerer på DPU, og som derfor ikke har modtaget mailen, der var sendt til deres DPU-mailadresse. Der var 52 studerende, som svarede på nogle eller alle spørgsmål.

Undersøgelsen inddrager studerende fra alle tre gennemløb af et modul med to forskellige udgaver (fremmøde og fjernstuderende), og det er forholdsvis få studerende, den bygger på. Resultaterne kan betragtes som en foreløbig befæstelse af de teoretiske overvejelser, jeg har gjort mig ovenfor.

I tabel 1 er gengivet de danskstuderendes gennemsnitlige svar på en skala fra 1 til 5 hvor 1 er mindst og 5 er mest. Jeg har valgt kun at sammenligne de danskstuderende fordi konteksten for deres forløb er sammenligneligt (samme fagunderviser, samme eksamensform, samme anvendelse af seminarer/fagdelt undervisning osv.). De studerende i København er fremmødestuderende $(n=19)$, de studerende i Århus er fjernstuderende $(n=12)$.

Det mest klare resultat er, at de studerende er mest aktive og lærer mest efter egen vurdering, når de skriver eksamensopgave og forbereder og går til eksamen. Dette resultat understøtter (Biggs, 1999), som siger, at der skal være alignment mellem undervisningens indhold og eksamen. Undervisningstilrettelæggelse skal, sat på spidsen, tage udgangspunkt $i$, hvordan eksamen skal foregå, og kan herefter tilpasse resten af modulet ud fra det. Eller - mere hensigtsmæessigt - tilrettelægge eksamen, så den så vidt muligt måler udbyttet af, hvad der er foregået $i$ undervisningen.

Et andet interessant resultat er, at de studerende angiver tal over middel for alle aktivitetsformer. Dette er en befæstelse af tesen om, at undervisningsmetoderne skal være varierede. De forskellige undervisningsformer fremmer forskellige aspekter af kompetenceudviklingen, og de studerende vurderer selv, at de lærer over middel af alle de anvendte former. Det må formodes, at det netop er i kraft af variationen, at de studerende angiver alle former til at være over middel 


\begin{tabular}{|l|c|c|c|c|}
\hline \multirow{2}{*}{ Aktivitet } & \multicolumn{2}{|c|}{ Aktivitetsniveau } & \multicolumn{2}{c|}{ Læringsudbytte } \\
\cline { 2 - 5 } & København & Århus & København & Arhus \\
\hline Forberedelse i form af læsning osv. & 4,1 & 3,7 & 3,9 & 3,6 \\
\hline Forelæsninger & 4,2 & 4,3 & 4,5 & 4,1 \\
\hline Skrivning af overblikspapirer/weblogs & 4,2 & 4,2 & 3,8 & 4,3 \\
\hline Deltagelse i fagdelt undervisning/seminarer & 4,0 & 3,8 & 3,0 & 3,9 \\
\hline Give/modtage respons på overblikspapirer/weblogs & 3,4 & 4,0 & 4,7 & 4,3 \\
\hline Skrive opgave/skrive synopsis/samle portefølje til eksamen & 4,6 & 4,8 & 4,4 & 4,2 \\
\hline Forberede og deltage i mundtlig eksamen & 4,5 & 4,8 & 4,0 \\
\hline
\end{tabular}

Tabel I. Studerendes vurdering af eget aktivitetsniveau og læringsudbytte ved forskellige undervisningsformer

(de må altså sammenholde deres vurdering med andre tilsvarende metoder - ellers kan alt jo ikke være over middel). En studerende forklarede sine vurderinger således:

Det var meget udbytterigt, at have lejlighed til at diskutere det "tilegnede" stof ved den fagdelte undervisning, og fă forskellige vinklinger på en problemstilling. Det var speendende og relevant indhold. Forelasningerne var også inspirerende, idet underviserne virkede utrolig motiverede. Overblikspapirerne blev nogen gange lidt for meget "et must do ", frem for et mere konstruktivt redskab. Men det var varierende.

Et enkelt tal skiller sig klart ud. Det er tallet for aktivitet og læringsudbytte ved responsgivning og -modtagning på overblikspapirer. De københavnske studerende angiver $i$ gennemsnit, at deres aktivitetsniveau var meget tæet på middeltallet $3(3,4)$, og at deres læringsudbytte er endnu lavere $(3,0)$. De århusianske studerende vurderer ligeledes responsgivning og -modtagning til at være blandt det mindre læringsrige, men dog slet ikke så lavt som de københavnske studerende. Dette tolker jeg som et eksempel på, at undervisningsformerne ikke kan vurderes som absolut gode eller dårlige uden for kontekst, men at det er den måde, de konkret er blevet udfoldet på, der er afgørende. En studerende på Københavns-holdet skrev i tilknytning til dette spørgsmål:

Responsen fra andre og til andre studerende ang. overblikspapirerne er sveer, når man ikke kender hinanden så godt eller hinandens emner. Det ville måske kreve meget faste rammer om, hvad responsen skulle indeholde ... og måske mere tid på de fagdelte hold...

De københavnske studerende skulle give hinanden respons på de overblikspapirer, som de skrev op til de fagdelte undervisningsgange (tre $\mathrm{i}$ alt). Men jeg havde placeret responsgivningen uden for undervisningstiden og vurderede, at det ville tage for meget tid fra de studerendes fagdelte undervisning, hvis de skulle følge op på den i timerne, hvor jeg var til stede. Responsgivningen var desuden ikke et krav for at få godkendt overblikspapirerne. For de århusianske studerende var responsgivningen på deres medstuderendes weblogs et delkrav for at fă afløsning for dele af eksamenskravet. Desuden fungerede kommunikationen i weblogs mere som en faglig diskussion end som en situation, hvor en »inkompetent« studerende giver respons, som burde være udført af en »kompetent« lærer.

En sidste interessant iagttagelse er, at der ikke er nogen betydningsfuld forskel på de københavnske og de århusianske studerendes oplevelse af aktivitet og læringsudbytte. Fjernstudier som dem, de Århusstuderende deltog i, er således ifølge denne undersøgelse ikke af ringere kvalitet end fremmødestudier.

\section{Konklusion}

Kritikken af traditionel universitetsundervisning har ofte baseret sig på henvisninger til den læringspyramide, som ved nærmere undersøgelser viser sig at være funderet på spekulative analyser af kommunikationsformer mere end på empiriske undersøgelser af læringsudbytte ved deltagelse $\mathrm{i}$ forskellige undervisningsformer. Et review af forskningslitteratur om undervisningsformer viser, at alle undervisningsformer har fordele og ulemper, og variation bliver derfor en mere videnskabeligt underbygget anbefaling til undervisningstilrettelæggelse.

I denne artikel præsenteres en krydsmodel over undervisningsformers organiseringstyper med modsætningen monologisk-dialogisk på den ene akse og lærerstyret-studenterstyret på den anden akse. Modellen kan fungere som en logik for undervisningstilrettelæggelse.

Jeg har i denne artikel gennem en analyse af fordele og ulemper ved en prototypisk undervisningsform inden for hver kvadrant argumenteret for, at det er en fordel at variere undervisningsformerne ved tilrettelæggelse af universitetsundervisning, således at der finder undervisning sted inden for alle fire kvadranter. Denne 
argumentation underbygger jeg gennem en empirisk undersøgelse af de studerendes opfattelse af læringsudbytte på et modul, der er tilrettelagt med undervisning inden for alle fire kvadranter i krydsmodellen. Den empiriske undersøgelse befæster argumenterne, men der er behov for en større empirisk undersøgelse af studerendes læringsudbytte på forskelligt tilrettelagte moduler.

\section{Litteratur}

Biggs, J. (1999). Teaching for quality learning at university. London: Taylor and Francis Inc

Bundsgaard, J. (2006). Nøglekompetencer med bud til de humanistiske fagområder. Cursiv (1), 2758. www.dpu.dk/cursiv

Dale, E. (1946). Audio-Visual Methods in Teaching. New York: Dryden Press

Dewey, J. (2005 (opr. 1916)). Demokrati og uddannelse. Århus: Klim
Johnson, D. W., Johnson, R. T., \& Stanne, M. B. (2000). Cooperative Learning Methods: A Meta-Analysis. Lokaliseret på www den 29. september 2008: www.co-operation.org/pages/cl-methods. html.

Jørgensen, P. S. (1999). Hvad er kompetence? Uddannelse, 9. København, Undervisningsministeriet.

Klafki,W. (2001). Dannelsesteori og didaktik - nye studier. Århus: Klim Lalley, J. P., \& Miller, R. H. (2007). The learning pyramid: does it point teachers in the right direction? Education 128(1), 16479.

Rychen, D. S., \& Salganik, L. H. (red.) (2003). Key Competencies for a Successful Life and a Well-Functioning Society. Cambridge, MA Hogrefe \& Huber Publishers.

Saroyan, A., \& Snell, L. (1997).Variation in Lecturing Styles. Higher Education 33(1), 85104.

Van der Vleuten, C. (1996). Beyond Intution. Inagural lecture. Maastricht: Universiteit Maastrict 